\title{
Safeguarding Traditional Villages in China: The Role and Challenges of Rural Heritage Preservation*
}

\author{
Mengyuan Zhou ${ }^{\mathrm{a}}$, Songfeng $\mathrm{Chu}^{\mathrm{b} * *}$ and Xiaofan $\mathrm{Du}^{\mathrm{a}}$ \\ a Department of Cultural Heritage and Museology, Fudan University, Shanghai, China \\ $b$ College of Architecture and Urban Planning, Tongji University, Shanghai, China \\ ** Corresponding author: chusongfeng@foxmail.com
}

\begin{abstract}
Since the reform and opening-up policy of 1978, China has established the double-track inventory system of rural heritage preservation to cope with the impact of rapid urbanisation on rural areas. This paper analyses the evolution in the concept of policy making from the Historical and Cultural Villages system to the Traditional Villages system. It argues that the mass recognition of Traditional Villages in China since 2012 indicates that the understandings of rural heritage have evolved from the distinguished to the diverse, the tangible only to the intangible included, and the material-based to the human-based. Under the rural revitalisation policy, the role of Traditional Villages in social development will be further explored and promoted as 'means of improvement', looking for the balance between protection and development of rural heritage in the urban-rural dual structure.
\end{abstract}

KEYWORDS rural heritage, historical and cultural villages, traditional villages

Received April 4, 2019; accepted May 17, 2019.

The discourse of safeguarding traditional villages in China requires to be viewed in the context of rapid urbanisation taking place in the country since the reform and openingup policy of 1978 .

Before 1980s, the rate of urbanisation in China was merely $20 \%$. It seemed unnecessary to put emphasis on the preservation of villages while most of the nation land was consisted of them. The economic reform, however, boosted urban industrial expansion and economic development with financial capital supplied by global investment, and human capital by surplus labour force from rural areas. The demand for spatial resources was soaring while urban population scales kept rising.

Since the 'Regulations of Land Expropriation for National Construction' were issued in 1982, the deconstruction and relocation of suburban villages had been taken as an inevitable course on the way to modernism (Kuai 2016). Numerous traditional villages disappeared in the

*This paper is based on the field study project organised by Centre for Land and Cultural Resources Research of Fudan University in 2018. The project is supported by the Ministry of Housing and Urban-Rural Development of China, in which a total of 137 interviews with villagers, social groups and departmental officials were conducted in five provinces, including Anhui, Zhejiang, Fujian, Guizhou and Shanxi. wave of urbanisation. Scholars and experts, however, started to make efforts to prevent the demolition of highly valuable historical districts and buildings in the full swing of city construction. The call for preserving the valuable past and the hope for a modernised and developed future contested with each other. This ideological and political conflict can be compared to the analogous development that took place in Europe during the $19^{\text {th }}$ century, when urbanisation and industrial revolution caused rapid social changes, and people felt an urgency to preserve the historical monument as well as their fading pastoral life.

Though the policy-making and implementation of rural heritage preservation was steps behind urban economic development plan, more than 30 years of practice have witnessed the process and challenges of safeguarding traditional villages in China. As fast as the country's economic and social development, the concept and strategies towards rural heritage constantly evolve in light of the circumstances, from which we can see several different phases:

1. 1978-1996: Urbanisation and Historical Cities

It was a period focused on urban planning. When planning a better future, some experts proposed that ancient 


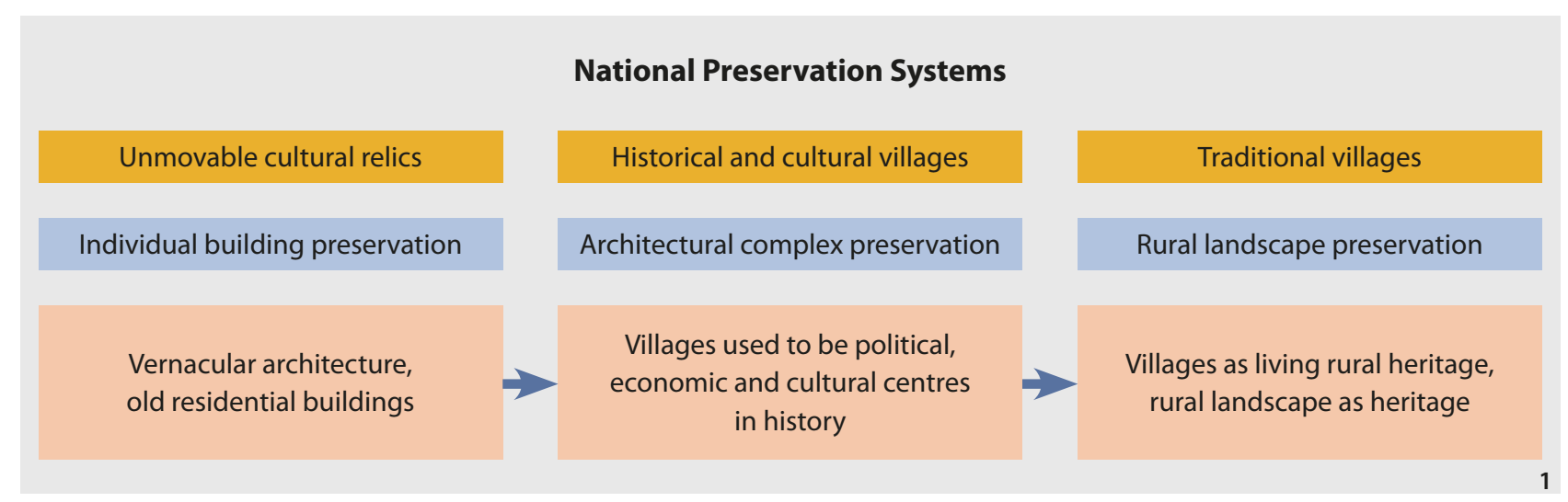

Figure 1 The ideological shift in rural preservation system in China (Source: the author).

cities with celebrated history should be regarded as unmovable cultural relics and be preserved. In the movement of protecting old buildings and historical blocks in cities, the built heritages located in countryside and villages were taken as a subsidiary issue. In nearly 20 years, the urbanisation rate went steadily from $20 \%$ to $30 \%$. With the Land Expropriation Policy issued in 1982, the Law on the Protection of Cultural Relics was enacted at the same year, during which 24 cities were listed as 'Historical and Cultural Cities' for preservation as national cultural heritage. The idea of protecting important architecture as unmovable cultural relics was eventually thought to be applied also to rural areas. In 1986 an official document indicated a tendency to broaden the list with old villages and towns, but this purpose was not carried out until the next decade.

2. 1997-2007: Distinguished Villages as Cultural Relics

With a rapid growth of urbanisation rate from 30\% to $45 \%$ in 10 years, the construction of small towns became a focal point of government work. A series of land policies and intervention measures were announced, in order to encourage local governments to regulate and construct small towns by relocating villagers and amalgamating villages in their administrative regions. However, it led to the vanishing of numerous traditional communities. Many old villages in remote areas that escaped the suburbanisation from the previous decade did not survive the migration project of this period (Kuai 2016). In 2003, as a response to this circumstance, the List of 'Historical and Cultural Towns and Villages' was officially announced. 22 distinguished towns and villages were included in its first batch, therefore credited with the title and taken under the tutelage of law. This indicated the establishment of one-track administrative system in the preservation of rural heritage in China.
3. 2008 till now: Rural Heritage as Improvement

The urbanisation rate in China has increased rapidly from $45 \%$ to $60 \%$ since 2008 . The List of China Intangible Cultural Heritage released in 2006 encouraged the public to concern with craftsmanship and folk activities endangered by declining country life. Instead of protecting a singular old building or vernacular architecture, academic studies and critics help to bring integrated preservation strategies into the scope of rural heritage preservation. Consequently, a new survey on national Traditional Villages started in 2012, from which more than 4,000 villages-many are insufficient in the identification of cultural relics but inheriting diverse landscapes and lifestyles-have benefited since then. The new list of Traditional Villages constitutes the dual-track administrative system, expanding the meaning and influence of rural heritage nationwide. Over the past decade, many Traditional Villages take heritage as resources to promote rural tourism and as powerful tools of poverty alleviation (Oakes 2013). Moreover, with rural revitalisation strategies carried out progressively, rural heritage is becoming one of the means to improve the quality of life for the rural population and to enroll the countryside in a more governmentalised state process in a broader context (Figure 1).

\section{The Ideological Shift in Rural Preservation System in China}

\section{What is Traditional Village?}

In the dual-track administrative system of rural heritage preservation, the concept of 'Traditional Villages' came after the list of 'Historical and Cultural Villages'. According to our field studies, most people (including tourists, visitors, and villagers) cannot distinguish the difference between the two titles, and simply refer to those listed in 
the system as 'Old Villages' in their daily conversation. This fact not only demonstrates the generality of age value shared by all the villages on the lists, but also questions the legitimacy and effectiveness of the current dual-track preservation system.

Then what are Traditional Villages? What makes them different from the Historical and Cultural Villages? If we compare the making process of the two lists, it is evident that there are different understandings of the purpose and value of rural heritage at different times.

The selection of Historical and Cultural Villages derived its idea and valuation system from Historical and Cultural Cities. With close connection to the amendment of Law on the Protection of Cultural Relics in 2002, Historical and Cultural Villages are associated with the concept of national cultural relics. Well-preserved buildings, pagodas, ancestral halls, and archaeological remains of outstanding historic value are regarded as crucial element in the recognition of a Historical and Cultural Village. Villages that used to be political, economic, or cultural centres in history, or provide the very place for important historical events, are more likely to be selected onto the list. In addition to the built heritage that has been witness of local stories of farming regimes and ways of rural life, a well-established local system of preservation and management of heritage occupied a decisive qualifying value in becoming a Historical and Cultural Village. These criteria lead to the 'high quality' of selected villages. Many villages have already established the measures and mechanism to maintain heritage before they enter the list, leaving behind those unable to afford so (Shao and Fu, 2012). Therefore, in the past 17 years, only 487 distinguished villages have been approved as Historical and Cultural Villages, most of which have well preserved their distinctive architecture and traditional settlement layout. The heritagisation process of these villages drives them to become important economic assets for tourism and related industries for local government. By 2017, according to an industry research report issued by ASKCI Consulting, the volume of China's domestic rural tourism has reached 2.8 billion person-time. The gross revenue of rural tourism of 2017 is over 740 billion $\mathrm{CNY}$, accounting for $16.2 \%$ of the total revenue of the domestic tourism industry (ASKCI 2018). Since the 1980s, when China first started to develop rural tourism, millions of middle class families have flocked to rural areas during the holidays, to enjoy farmhouse food and fresh air. Undoubtedly, ancient villages with historical architecture and folk culture have become popular choices. With the rapid expansion of the rural tourism market, heritages in rural areas face multiple pressures ranging from environmental pollution to illegal demolitions and reconstructions done by developers. In order to form a regulated and sustainable market model, the involvement of tourism management sectors is necessary. With the State Tourism Administration taking full participation in the management and development of the Historical and Cultural Villages system in 2009, the 'Regulations on the Preservation of Historical and Cultural Cities, Towns and Villages' issued in the previous year can be viewed as a legal measure to restrain the growing economic market of rural tourism.

The ideological shift on rural heritage preservation took place around 2008. Multiple international conferences held in China since 2006 brought in new visions and frontier research on global rural heritage preservation. In 2008, scholars, officials and UNESCO experts gathered in Guiyang to attend the International Conference on the Preservation and Development of Rural Cultural Landscape. On the meeting, all participants voted to approve a document later named The Proposal of Guiyang, in which the concept of 'rural cultural landscape' was officially introduced. The new idea employed the definition of Cultural Landscape from the World Heritage system, promoting traditional villages as 'combined works of nature and of man' (Zhang, 2011). It broadened the scope of rural heritage from vernacular architecture to the historic environment modified and transformed by farmers in the course of time. Thus the core values of traditional villages were liberated from tangible monuments and buildings, bringing intangible culture, traditional lifestyle and rural landscapes into the value judgment system. It not only highlights the dynamic process between human and nature in the creation of rural landscape, but also brings new perspective into the recognition of the Traditional Villages system. If we compare the criteria in the assessment and selection process of the Historical and Cultural Villages $(2003,2008)$ with that of the Traditional Villages (2012), the extended value space in the identification of rural heritage will be self-evident (Table 1).

In the process of selecting a Traditional Village, the county government, in most cases, will encourage and organise the self-nominating documents for villages in its area of jurisdiction. The fact that the project of Traditional Villages offers a subsidy particularly increases attraction to impoverished counties. Most of the applications will get strong support by provincial departments during the preliminary assessment, because each province wants to maximise the number of its applicants thus to promote 
Table 1 Criteria in the recognition of Historical and Cultural Villages vs Traditional Villages from documents (Source: the author).

\begin{tabular}{|c|l|l|}
\hline Year & \multicolumn{1}{|c|}{ List } & \multicolumn{1}{c|}{ Criteria } \\
\hline 2003 & $\begin{array}{l}\text { Historical and } \\
\text { Cultural Villages }\end{array}$ & Historical value; featured landscape; condition of being authentic; current status and management \\
\hline 2008 & $\begin{array}{l}\text { Historical and } \\
\text { Cultural Villages }\end{array}$ & $\begin{array}{l}\text { Ubed to be political, economic, or cultural centre in history, or provide the very place for important historical } \\
\text { landscape; } \\
\text { events, or reflect collective cultural and ethnic features }\end{array}$ \\
\hline 2012 & $\begin{array}{l}\text { Traditional } \\
\text { Villages }\end{array}$ & $\begin{array}{l}\text { Well-preserved traditional architecture; or traditional site selection and settlement layout; or living intangible } \\
\text { cultural heritage }\end{array}$ \\
\hline
\end{tabular}

the competiveness for the national list: this is also how some of the provincial lists are normally made. When the application materials are submitted to the administrative ministry, experts and scholars from different backgrounds will be invited to rate each village according to certain criteria. The assessment process leads to the final List of Traditional Villages of China. As a result, a great deal of villages previously unqualified for the title of Historical and Cultural Villages were enrolled onto the List of Traditional Villages since 2012. By now, there are 6,819 traditional villages on the official list and the number of traditional villages on the provincial level will even multiply. This represents how the understandings of rural heritage have evolved from the distinguished to the diverse, the tangible only to the intangible included, and the material-based to the human-based.

Formed by people living on and cultivating land over hundreds of years, Traditional Villages are recognised as living heritage that carries the memory and wisdom of human settlement from agricultural civilisation. In the wave of urbanisation, many villages have disappeared and more are disappearing. What disappears with them are senses of place, diverse identities and traditional ways of life. Improving the understanding of rural heritage not only helps us to remember where we are from, but also provides opportunities to work with the direction of future change and improve our habitat restoration.

\section{The Role of Traditional Villages}

The international paradigm of rural landscape can be dated back to the 1980s. When Cultural Landscapes were first recognised and protected by the World Heritage Convention in 1992 as an individual heritage type, they fell into three categories, namely: (1) the clearly defined landscape designed and created intentionally by man; (2) the organically evolved landscape; (3) associative cultural landscape.

Rural landscape was categorised into the second type, as the continuing landscape that 'retains an active social role in contemporary society closely associated with the traditional way of life, and in which the evolutionary process is still in progress'. In order to explore common principles, cognitive methodologies and ways of management of rural landscape worldwide, the ICOMOS-IFLA International Scientific Committee on Cultural Landscapes (ISCCL) launched the World Rural Landscapes Initiative (WRLI) in 2011. The outcome, Principles Concerning Rural Landscape as Heritage, was adopted as a doctrinal text by ICOMOS in 2017. The paper defines the concepts of 'Rural Landscape' and 'Rural Landscape as Heritage' theoretically, guiding different countries to understand and protect rural landscapes and their heritage value:

Rural landscapes are multifunctional resources. At the same time, all rural areas have cultural meanings attributed to them by people and communities: all rural areas are landscapes ...

Rural landscape as heritage refers to the tangible and intangible heritage of rural areas. Rural landscape as heritage encompasses physical attributes ... as well as wider physical, cultural, and environmental linkages and settings. Rural landscape as heritage also includes associated cultural knowledge, traditions, practices, expressions of local human communities' identity and belonging, and the cultural values and meanings attributed to those landscapes by past and contemporary people and communities.

The dual-track inventory system of China in many ways contributes to the drawing-up of the Principles. (Scazzosi, Wang and Li 2018) The universality of rural landscape, 
Table 2 The economic situation of the top 10 provinces in the Traditional Villages quantities (Source: the author).

\begin{tabular}{|c|c|c|c|c|c|c|c|}
\hline Province & $\begin{array}{c}\text { Number of } \\
\text { traditional } \\
\text { villages }\end{array}$ & $\begin{array}{c}\text { Rate of } \\
\text { urbanisation } \\
2017(\%)\end{array}$ & $\begin{array}{c}\text { Change of } \\
\text { urbanisation } \\
\text { rate 2012-2017 } \\
(\%)\end{array}$ & $\begin{array}{l}\text { GDP per } \\
\text { capita } \\
(\mathrm{CNY})\end{array}$ & $\begin{array}{l}\text { Proportion of } \\
\text { primary sector } \\
\text { in GDP (\%) }\end{array}$ & $\begin{array}{c}\text { Per capita } \\
\text { disposable } \\
\text { income in rural } \\
\text { area }(\mathrm{CNY})\end{array}$ & $\begin{array}{c}\text { Per capita } \\
\text { disposable income } \\
\text { between urban and } \\
\text { rural areas }\end{array}$ \\
\hline Guizhou & 725 & 46.02 & 9.61 & 37956 & 15.0 & 8869.1 & 3.28 \\
\hline Yunnan & 709 & 46.69 & 7.38 & 34221 & 14.3 & 9862.2 & 3.14 \\
\hline Hunan & 657 & 54.62 & 7.97 & 49558 & 8.8 & 12935.8 & 2.62 \\
\hline Zhejiang & 635 & 68.00 & 4.80 & 92057 & 3.7 & 24955.8 & 2.05 \\
\hline Shanxi & 545 & 57.34 & 6.08 & 42060 & 4.6 & 10787.5 & 2.70 \\
\hline Fujian & 492 & 64.80 & 5.20 & 82677 & 6.9 & 16334.8 & 2.39 \\
\hline Anhui & 400 & 53.49 & 6.99 & 43401 & 9.6 & 12758.2 & 2.48 \\
\hline Jiangxi & 343 & 54.60 & 7.09 & 43424 & 9.2 & 13241.8 & 2.36 \\
\hline Sichuan & 333 & 50.79 & 7.26 & 44651 & 11.5 & 12226.9 & 2.51 \\
\hline Guangxi & 275 & 49.21 & 5.68 & 38102 & 15.5 & 11325.5 & 2.69 \\
\hline $\begin{array}{l}\text { National } \\
\text { Statistics }\end{array}$ & 6819 & 58.52 & 5.95 & 59660 & 7.9 & 13432.4 & 2.71 \\
\hline \multicolumn{8}{|c|}{ Indicators lower that national average statistics } \\
\hline
\end{tabular}

which is underlined in the document, was manifested and practiced in the mass recognition of Traditional Villages. Though the difference between the terminologies of 'rural landscape' and 'rural heritage' is still under debate, the consensus of preserving tangible and intangible heritage in rural areas as integration is adopted as an international guideline. Besides the shared vision and values at the global scale, nevertheless, the Traditional Villages system has its unique significance in the economic, social and political context of contemporary China.

As one of the leading developing countries, China faces different problems and tasks in policy-making and management of rural area when compared to developed countries in the Europe and America. Even today, after 40 years of opening-up and reform, the urbanisation rate indicates that there is approximately $40 \%$ of population, bound to the hukou registration system, is attributed to rural households and owning land and houses in countryside. Therefore, the heritagisation process of the Traditional Villages is destined to explore its own meaning to local communities and to the rural areas. What role will Traditional Villages play in the development of future China? The approach to the question shall be further explored through vernacular practice and its experience.

The preservation of traditional villages is deeply affected by the process of urbanisation and industrialisation. With high-quality education and medical resources concentrating in urban areas, labour force flocking in towns and cities in search of job, leaving old people and children behind villages. Hollowed and culturally aging, the historic self-sufficient villages cannot meet the needs of modern life any more. Today's China is no longer an agricultural economy. The proportion of agriculture in GDP has fallen below $10 \%$. The main body of job creation is the urban economy. Moreover, in cities with larger scale and higher per capita education, the unemployment rate is lower. It is no wonder that more and more young generations who hold rural hukou choose to work in big cities. Accorduing to the interviews conducted by the authors in Zhuge Village in Zhejiang Province, young people who were born in the village have refused considerable salaries provided by the villagers, and sought jobs with less income in big cities, only to enjoy the convenience and industrial products of modern city life.

Traditional Villages are geographically concentrated in China's undeveloped provinces. The economic factors are both the driving cause and financial pressure in the preservation of rural heritage. By analysing the socioeconomic data of the top 10 provinces in the number of Traditional Villages (Table 2), it can be seen that: (1) Only two provinces, Zhejiang and Fujian, have per capita GDP exceeding the national average; (2) Only Zhejiang and Fujian provinces have higher urbanisation rates than the national average at the end of 2017, while the urbanisation rates of the other eight provinces are much lower. In addition, among the seven provinces, the urbanisation rate of the past seven years has changed more than the national average. The trend of rapid urbanisation inevitably 
affects the loss of population in a large number of traditional villages; (3) The village is still in a weak position in the urban-rural dual structure. The per capita disposable income of rural areas in the eight provinces is lower than the national average. In these less developed provinces, the level of urban and rural consumption varies greatly. The difference between rural income and urban income is so large that it will inevitably attract villagers to work in cities in pursuit of higher wages.

From a global perspective, with the development of industrialisation and urbanisation, despite some countries have entered the stage of 'reverse urbanisation', the general decline of the rural areas has become an indisputable fact. It is seen as a crisis of cultural identities in China. Thousands years of nomadic and farming history have spawned splendid agricultural civilisation in the country, and many agricultural cultural heritages still play important roles in both material and spiritual levels in people's lives. The rapid urbanisation in 40 years means that most of the population still remembers what their hometown looks like as a little town or village. The general decline of the countryside is a signal of national economic boom, but also a disconnection with the collective memory and cultural roots, to which most of the Chinese elites will never happily accept.

\section{Driving Force and Top-Down Approaches}

Pastoral life has significant meaning for literati class of Chinese people. Escaping from the political struggle in the capital city to pursue settlement in the countryside has been the symbol of ideal eremitism since Tao Yuanming. Rural life, as a cultural tradition, stands for the symbolic 'alternative' for the men of letters. They may not practice the migration to the countryside but they always yearn for the possibility of choice. Therefore, the emotions of cultural elites toward rural China are complex. As Oakes has observed:

Rural China's cultures of display appear to derive from two seemingly contradictory traditions: viewing the village, on the one hand, as a representation-a sort of model-of harmony prosperity, and social order, and, on the other hand, as a site lacking these very qualities and, thus, in constant need of transformation under the leadership of external cultural elites. (Oakes 2013)

Experts and scholars have always played important role, if not the leading character, in the preservation and utilisation of rural heritage in China. Since the early $20^{\text {th }}$ century, scholars like Zuoren Zhou and Xiaotong Fei have sought ways to construct a modernised country and new national identity through transformation and cultivation of village community. From the 1980s, Professor Renzhi Hou, Xiaoxie Zheng and Shiyuan Shan presented the proposal of Historic City Conservation plan to the government, which directly led to the form of Historical and Cultural Cities system (Zhang 2012). Meanwhile in the 1980s, academics from architectural background formed groups to start field study in rural areas, aiming to 'rediscover' traditional villages and redefine the beauty and values of vernacular architecture in rural China. The survey groups led by Zhihua Chen and Qiuxiang Li brought expert knowledge to villagers and grassroots cadres while they conducted field study over the country. The early field works not only pave the way for Plan-led System in the future management of traditional villages, but also made significant impact on how local officials and villagers view their properties through the face-to-face communication.

Behind the continuing efforts made by scholars and experts, the systematic management and preservation process of rural heritage in China adopts top-down approaches. In order to cope with the complex and mutable conflicts in the practical field, the departments and bureaus involved in the management system have been adjusted over time, forming the multi-sectoral regulation system. Concerning the tangible rural heritage, the major actors are the Cultural Heritage Administration and the Ministry of Housing and Urban-Rural Development, and their equivalents at provincial, municipal, county and township levels. Concerning the intangible rural heritage, the major actors are the Ministry of Culture and its local offices (Svensson 2016). The Tourism Administration and its branch offices have involved in the development of Historical and Cultural Villages since 2009. By the year of 2015, on behalf of the Traditional Villages project, the Ministry of Finance, the Ministry of Land and Resources, the Ministry of Agriculture and Rural Affairs have issued a joint statement to ensure the promotion of Traditional Villages preservation works (Table 3).

We can detect the development within the approach to rural heritage from the growing institutions and departments involved in the management. The Traditional Villages system, ideally, shall link the various administrative departments to promote effective networks and to ensure governmental coordination. In fact, the mechanism construction and practical operability related to the management and preservation of Traditional Villages can hardly keep up with the development of macro-ideology. The preservation and supervision of traditional villages is managed 
Table 3 The departments participated in the management of rural heritage (Source: the author).

\begin{tabular}{|c|c|c|}
\hline Year & Institutions and departments involved & Document \\
\hline \multicolumn{3}{|c|}{ Historical and Cultural Cities, Towns and Villages } \\
\hline 1982 & Cultural Heritage Administration & $\begin{array}{l}\text { Law of the Peoples Republic of China on Protection of Cultural Relics, } \\
\text { Article } 3 \text {, Article } 8\end{array}$ \\
\hline 1986 & $\begin{array}{l}\text { Cultural Heritage Administration, } \\
\text { Ministry of Construction, } \\
\text { Ministry of Culture }\end{array}$ & $\begin{array}{l}\text { 'Notice of the State Council on the Approval of the Ministry of Construc- } \\
\text { tion and the Ministry of Culture on Applying for the Enactment of the } \\
\text { Second Batch of National Historical and Cultural Cities' (Guofa [1986] } \\
\text { No. 104) }\end{array}$ \\
\hline 2009 & $\begin{array}{c}\text { Ministry of Housing and Urban-Rural Development, } \\
\text { Tourism Administration }\end{array}$ & $\begin{array}{l}\text { 'Notice on the Demonstration Work of Famous Towns (Villages) with } \\
\text { Characteristics Landscape' (Jiancun [2009] No. 3) }\end{array}$ \\
\hline 2012 & $\begin{array}{l}\text { Ministry of Housing and Urban-Rural Development, } \\
\text { Cultural Heritage Administration }\end{array}$ & $\begin{array}{l}\text { 'Requirements for the protection plans for Historical and Cultural Cities, } \\
\text { Towns and Villages' (Jiangui [2012] No. 195) }\end{array}$ \\
\hline \multicolumn{3}{|c|}{ Traditional Villages } \\
\hline 2012 & $\begin{array}{l}\text { Ministry of Housing and Urban-Rural Development, } \\
\text { Ministry of Culture, } \\
\text { Cultural Heritage Administration, } \\
\text { Ministry of Finance }\end{array}$ & $\begin{array}{l}\text { 'Notice on the Investigation of Traditional Villages' } \\
\text { (Jiancun [2012] No. 58) }\end{array}$ \\
\hline 2015 & $\begin{array}{l}\text { Ministry of Housing and Urban-Rural Development, } \\
\text { Ministry of Culture, } \\
\text { Cultural Heritage Administration, } \\
\text { Ministry of Finance, } \\
\text { Ministry of Land and Resources, } \\
\text { Tourism Administration, } \\
\text { Ministry of Agriculture and Rural Affairs }\end{array}$ & $\begin{array}{l}\text { 'Notice on Doing a Good Job in Protecting Chinese Traditional Villages } \\
\text { in 2015' (Jiancun [2015] No. 91) }\end{array}$ \\
\hline
\end{tabular}

locally. Under the joint supervision and administration system, the main bodies of the preparation, implementation, monitoring and management of preservation plans are different, resulting in unclear division of duties, which makes the relevant local departments compete for powers while shirk from responsibilities. The unclear subject of liability greatly reduces administrative efficiency and is not conducive to the preservation of Traditional Villages.

In some provinces, Zhejiang for instance, the provincial government adopts an independent and exploratory approach to manage its Traditional Villages. As a province with a leading economy and great management awareness, Zhejiang Province pioneers its administrative system with a provincial list on which more than 2,000 traditional villages are catalogued. This provincial list is so ample that it incorporates all of the 44 Historical and Cultural Villages and 635 Traditional Villages in its administrative region, and becomes the major object of provincial rural heritage management. Instead of the Department of Housing and Urban-Rural Development (DHURD), the leading unit in the arrangement of subsidy of Traditional
Village in Zhejiang Province is the Office of Agriculture and Rural Affairs (OARA). It coordinates all financial funding that associates with rural policies and has a high status in grassroots work. However, some officials in the DHURD have pointed out the conflicts and controversies in the coordination of different rural projects due to OARA's insufficient professional knowledge. The project of Beautiful Villages, for instance, a rural campaign led by OARA that aims to improve the looks and 'tidiness' of villages since 2008, has spent lots of money on the beautification of numerous villages in the province, in order to improve the quality of life for rural inhabitants. Although the requirements and focus of the application criteria for the two projects are different, in the practical operation of the city-level and county-level agricultural offices, the project funds of the Beautiful Villages and subsidy of the Traditional Villages are sometimes distributed to the same village, which of course can achieve greater governance effects. However, when 'beautifying' the village, some cost, like painting white walls and commissioning traditionalstyle graffiti, is seen by officials in the housing sector as 
another form of damage to the vernacular architecture. In an interview with the DHURD of Zhejiang Province in 2018, one of its officials blamed the OARA for 'not knowing how to spend money properly'. This kind of similar complaint is found in other provinces as well.

In the first two decades since the opening-up policy, the Cultural Heritage Administration has been the leading department in the conservation of Historical and Cultural Cities. Therefore, the existing protection policy is rooted in and evolves from the cultural relics protection system, in which the physical restoration of an object is placed at the core of its management work. The management experience and methodologies are applied first to the Historical and Cultural Villages, then to the Traditional Villages, lacking of research on rural-urban differences and specific conditions of traditional villages. The Preservation Plan-led System, regulated by the Ministry of Housing and Urban-Rural Development and its local equivalents, serves for the protection of authenticity and integrity of old buildings in core area. It has been the central task of departmental management work of rural heritage preservation for many years. To quote Professor Zhihua Chen, 'what we want to retain are just a few specimens of history'. Viewing villages as 'specimens' implies mummifying villages in the time. The whole villages are regarded as outdoor museums, in which architecture is the permanent collection on display and villagers are merely dispensable.

Consequently in many traditional villages, there are two preservation patterns of the status quo: (1) In villages with tourism economic value, local governments and development enterprises use protection and use of vernacular architecture as the excuse to move all the villagers out. Thus the responsibility and overall interests of traditional villages are given away to enterprises, depriving the individual interests of the aborigines. (2) In villages of geographically disadvantage, local department officials struggle to stop villagers from demolishing old houses and building European-style new ones, despite the fact that old buildings are no longer livable for younger generations who are craving for modern life. The divergence between the need of re-construction from villagers and the implementation of regulation from officials sometimes causes tensional conflicts.

There are certain differences between the 'static' management model of the Historical and Cultural Villages and the requirement of overall preservation, developing preservation and cultural preservation of rural landscape. As early as 2008, the overall maintenance of the material space and cultural value of rural heritage preservation has been approved and promoted by the academic community. The ideological shift advanced the mass recognition of Traditional Villages in 2012. However, the institutional design and administrative measures that can support and serve the new idea have not been studied or promoted thoroughly. The contradiction between the current conservancy system and the evolving understanding and goals of rural heritage preservation is one of the biggest challenges of our time.

\section{Heritage as Improvement}

Many scholars have noticed that the majority of Chinese experts, officials, and even villagers themselves view the heritage preservation in China as a powerful tool to shake off poverty and fulfil modernisation. (Oakes 2000, 2013; Nitzky 2012) It has been written and affirmed officially, since 2013, by the Document No.1 of the Central Government of the Communist Party for six consecutive years. In these guiding documents, rural heritage preservation is an important part of a national strategy aiming for the improvement and development of China's countryside.

If we analyse the documents issued by the central government over the past seven years (State Council, 2013-2019), we can observe that: (1) The terminology of 'Traditional Villages' has fully taken over the 'Historical and Cultural Villages' in the context of rural development strategies, as the previous appears eight times and the latter only one. (2) From 2013 to 2016, regarding the Traditional Villages project, the central government's work has focused on the completion of an inventory, preparation for preservation plans and improvement of departmental regulation and supervision. (3) Yet since 2017, the guidelines of 'healthy, moderate development' has been introduced to the management objectives of the Traditional Villages system, encouraging the adoption of rural heritage as resources to develop tourism and industries with local advantages.

The $19^{\text {th }}$ National Congress of the Communist Party of China took place in 2017, in which the Rural Revitalisation Strategy was declared and put forward nationwide in priority at the present stage. The Rural Revitalisation Strategic Plan released in 2018 further shows the government's methods and focus in rural issues, whose aims are narrowing the urban-rural gap, driving industry to support agriculture, and promoting urban capitals and recourses to stimulate rural development. Among them, the role played by the Traditional Villages project is the identification of 'villages with special resources', a type of category different from 'common villages', 'suburban villages' and 'villages with migration needs' in the country. Though the 
unique routes and approaches to 'balance the requirements of preservation, utilisation and development' of rural heritage need to be further explored in a systematic reformation context, the purpose of heritage as rural improvement is top-level designed.

In fact, the Traditional Villages project has already been promoted as the impetus to improve living conditions for communities in remote and backward area. Different from the nature of 'honorary title' of Historical and Cultural Villages, Traditional Villages system provides financial funding to villages catalogued on the list. With the preparation and approval of preservation plan, each Traditional Villages can receive a subsidy of 3 million CNY. In some richer areas, Zhejiang Province for instance, provincial and regional subsidy funds will be allocated as further support to the central policy. These subsidy funds are earmarked for the improvement of village infrastructure, such as sewage treatment, garbage remediation and toilets improvement, aiming to transform the public areas of Traditional Villages clean and beautiful, thus suitable for modern people's living and visiting.

In a Notice issued in 2014 by joint Ministries, the subsidy of Traditional Village project is encouraged to be coordinated with other special funds and to support: (1) demonstration projects of preservation and reuse of traditional architectures, (2) disaster prevention facilities, (3) restoration of historical environmental elements, (4) improvement of infrastructure such as sanitation and public environmental remediation, (5) protection of cultural relics, (6) preservation of national intangible cultural heritage. In the practical field, many local authorities, in order to pursue fairness and impartiality, are more inclined to use the subsidy in the disaster prevention facilities, public environmental renovation and infrastructure improvement, because these are welfares for the whole villages. But the details and procedures vary from case to case according to local governance.

Gaoping City of Jincheng City, Shanxi Province, for instance, has established a local approach to managing the 17 Traditional Villages in its region. The city Housing and Urban-Rural Development Bureau (HURD) and the township government jointly manage the project of Traditional Villages. The township government will find planning offices with license to draw up the preservation plan for each Traditional Villages, then submit to the city HURD for approval. The HURD supervises the use of the subsidy by inspecting the Preservation Plan. The city Finance Bureau, the Environmental Protection Bureau and the Cultural Heritage Bureau will also give review and revision opinions one by one, and investigate the project budget. In the end, village representatives and township government will coordinate the bidding and implementation process of the project together.

Although the subsidy mechanism has attracted a large number of impoverished villages to join the application, in the actual operation process, according to our field study, both financial management system and practical situation caused difficulties in the rational distribution of funds. In some old villages, Xinye Village in Zhejiang Province for instance, the densely arranged ancient buildings make the electrical wiring and pipe laying works extremely challenging. The buildings, which were identified as national cultural relics and protected by law, are too valued for local officials to take the risk. Thus the modernisation plan is postponed indefinitely. In some others, the infrastructure engineering was completed years ago, which results in the incapability of spending the Traditional Villages subsidy.

China's unique political and economic system determines the government-led mechanism in both urbanisation and countryside administration (Li, Chen and Liu 2012). Though a lot of studies have pointed out that, with the top-down approach, it is possible to mobilise capital and resources to achieve political and economic goals in a short period, however, it is disadvantageous to the cultivation of long-term mechanism for rural communities and the sustainable development of the countryside (Zhou and Zhong 2015; Xu and Lu 2011). In the Rural Revitalisation Strategic Plan, the authorities have appealed to the public to form a 'sustainable mutual promotion mechanism for the preservation of rural heritage and the development of villages'. The preservation and utilisation of rural heritage as a means of improving rural life, is bound to be the goal of the development of China's countryside in the next stage. The Traditional Villages system, with first-phase preparation of inventory and catalogues at all scales, will be an important starting point for the next-phase projects of mediation between heritage preservation and rural development. How to guard the rural heritage while transforming it into valuable resources for the current and future life of communities? The challenges not only lay on the improvement in the understandings of the core value of rural heritage, but also in the reform of land policies, the innovation of mechanism, and the amendment of regulations and laws.

\section{The Challenges of Traditional Villages}

\section{Is Tourism the Ultimate Solution?}

Many local Chinese officials and villagers have viewed rural tourism project as the most efficient means to 
achieve economic growth in the development of countryside. Since the field study visit of scholars from 1980s, some grassroots cadres with keen eyes soon became aware of the potential economic value of their assets and propelled architecture preservation works in villages. Zhuge Village, one of the leading examples, took measures to restore old buildings as early as in the 1990s, organised by village cadres right after the visit of scholars, aiming to provide an authentic historic environment for the development of sightseeing tour. According to the interview with village leaders, the ticket proceeds and tourism income of Zhuge Village has reached 20 million CNY in 2018, and achieved self-sufficiency in the heritage conservation cost and subsidies for the elderly in the villages in general. Zhuge Village has been considered as the 'model' for rural development through tourism, earning accolades for the achievement of both heritage protection and economic and social development for the collective interests of the village. Nevertheless, the bottomup Zhuge Mode is not easy to replicate in other areas, as several critical conditions are crucial in its development history: (1) The grass-roots elites, as members of the lineage, actively work with scholars from outside and stably lead the community for more than 20 years; (2) The village itself owns advantaged conditions for tourism development, including the perfect village scale and maze-like layout for sight-seeing, with the cultural attraction of an ancestor, Zhuge Liang, who is the most well-known and popular military counsellor in Chinese history; (3) The community empowers the collective economy organisation to found a tourism company, so that it can develop rural tourism through market-oriented operation. The profits are used for repairing old buildings collectively owned and back-feeding the individual members.

The case of Zhuge Village represents the best that tourism industry can bring to rural heritage. There are more villages, however, in pursuit of tourism development and financial reward, going further than preservation. Re-invention of intangible cultural heritage as performance and re-construction of counterfeit 'old' buildings, which often is led by outside tourism companies, turns the folk life of many villages into a spectacle for tourists. While villagers often concern about the competition of neighbouring villages in tourist attraction, many experts concern about the tourism industry as a major contributor to the destruction of rural heritage. Because on one hand, rural tourism construction always leads to ecological degradation and environmental damage, on the other, once the local community has proposed, they would improve their quality of life by building new houses, roads and facilities following urban construction fashion style (Gao, Huang and Huang 2008). Additionally, too much commercialisation is considered to be harmful to the inheritance of traditional and ethnical culture.

Eco-museum projects are considered as alternative practice besides tourism development in rural heritage preservation. The concept of eco-museum was introduced to China in the mid-1980s, and was first implemented by scholars and officials as experimental initiative of rural heritage preservation in Guizhou Province in 1997. In the past two decades, the movement has spread nationwide. Eco-museums have been established in Guizhou, Guangxi Zhuang Autonomous Region, Inner Mongolia Autonomous Region, Xinjiang Uygur Autonomous Region, and more regions are planning to join the movement. The purpose of eco-museum project is to build a local, community-based initiative for community participation and engagement in heritage preservation and management (Davis 1999). A documentation centre, which functions as an exhibition place to welcome the visitors, and as a library to catalogue documented and recorded work on local culture, is considered to be the fundamental characteristic of an eco-museum in China. Compared to the rural tourism, the ecomuseum projects put more emphasis on rural landscape protection while keeping to the appeals of development. It is concluded that the eco-museum pursues the concept of 'sustainable activity' rather than a mere 'agent of development?. However, recent studies have pointed out that the Chinese practice of eco-museum fails the decentralisation principle of original Scandinavian concept, resulting in negative effects not only for the economic development through tourism, but also for community improvement (Nitzky 2012).

In the context of the rural revitalisation strategy, Traditional Villages is asked not to hinder development because of 'static' protection plan, nor to break through the bottom line of preservation for development. The requirement of balance between preservation, utilisation and development of rural heritage is extremely challenging. Regarding the future of China's countryside, is tourism the ultimate solution for rural revitalisation? In a conversation with an official from the Department of Housing and UrbanRural Development, the man offered his opinion that onethird of Traditional Villages in his province has the potential value for tourism development. When asked where will the two third of other villages go, he fell silent.

The answers to the question need to be explored through value assessment of Traditional Villages. It is 
commonly known that value assessment is the most significant part in the process of preservation and management of cultural heritages worldwide. The assessment itself could considerably decide the follow-up strategies to determine the scope and means of protection of the historical site (Zhou and Du 2019). The rural landscape contains time and space, reflecting the political, social and cultural constructs. They evolve over time, with various human activities, so the multi-layered meaning of rural heritage needs to be explored through multidisciplinary visions (Taylor 2007). The exploration of new methodologies and actions shall be promoted under the guidance of cross-disciplinary cooperation. Only with historians, anthropologists, sociologists, economists, architects and agriculturists working together, can the core values of each village be re-assessed and revealed, leading to a better plan for the Traditional Villages' future.

\section{How to Improve the Dynamic Mechanism?}

The maintenance and conservation of vernacular architecture is an endless job. The financial burden cannot and will not be borne solely by the government, therefore it is very important to study and seek the motivation from the rural inhabitants.

From the perspective of people's subjective will, the preservation of rural heritage can be divided into 'active preservation' and 'passive preservation'. 'Active preservation' refers to the bottom-up approach in which villagers and stakeholders spontaneously take part in the restoration and maintenance of traditional houses and landscape. In Fujian, Zhejiang and Guizhou, lineages and religious associations still play active role in the restoration of temples and ancestral halls. Many lineage members who live in other places, including abroad, will still contribute money to the maintenance and conservation of ancestral halls annually (Svensson 2016). The bottom-up driving force not only benefits the group cohesiveness of the village in a long term, but also strengthens the social relationship and identities of the villagers.

The 'passive preservation', however, resulted by the top-down management effect, is how most of residential architectures in China preserved at the moment. Limited by land policy and household registration system, many ex-farmers are bound to live in the countryside. When their old houses are designated as heritage and thus restrained from demolition or reconstruction, their frustration and incomprehension intensifies with the yearning for a modern life. The problem will be more complicated when it comes to the restoration funds. The disputes over property rights and the shirking of responsibility have led to the continuous decay of historical buildings, making each interested party to passively wait for the government to finally fund the restoration.

Without the quality of living for rural inhabitants effectively improved, the villagers shall not truly recognise and approve the discourse of rural heritage led by experts and promoted by the government. The establishment of the Traditional Village system has revolutionised the concept of historical buildings as precious cultural relics, and promoted the universality and diversification of rural heritage values to a large extend. But without supporting land policy, market mechanisms, governance solutions, theoretical guidance and cultural promotion, the idea of evolving rural landscape as heritage cannot be implemented in reality.

In a government-led economic and political society, there are some issues need to be addressed in the motivation of 'active preservation' mode of Traditional Villages in China:

1. Establish the property right system for rural heritage. In many traditional villages, there are different families living in one courtyard-style building, often resulting in disputes on property rights. In the absence of 'confirmation of property rights' of each building, the housing ownership can involve families, collective economic organisation and tenants, which tends to shift the blame to each other's shoulder when it comes to repair and maintenance. Exploring the breakthroughs and reforms in the policy of 'separation of houses and land' and the policy of using homesteads in Traditional Villages is urgent. If the land property rights are transformed to the collective economic organisation of the village, while the houses on the land to be utilised and developed by investors, this will allow the villagers to gain benefits from the implementation of the leasing and trading of their buildings. The introduction of market mechanisms will further attract social capital to participate in the preservation of rural buildings in Traditional Villages, promoting the cooperation among non-governmental organisations, universities and social force.

2. Improve education in rural areas and cultivate local talents. In the future, rural education needs to emphasize on the introduction of local knowledge and ability education, so that young generations in the countryside can establish identities and gain cultural confidence from school. The concept of rural heritage preservation should be introduced to elementary education. Trainings on rural planning, construction, and traditional techniques should be encouraged, providing resources 
and opportunities for local talents to participate in the management and preservation of rural heritage.

3. Promote extensive and ongoing cooperation between public institutions, universities and villages. Insufficient in the quantities of NGO, scholars and experts have been the significant driving forces in the preservation of rural heritage in China. With the paradigm shift of critical heritage studies since 1960s, many scholars start to rethink and promote the entitlement process in the preservation of Traditional Villages. In the future, scholars will be required to stay in the countryside for a longer period of time, to establish long-term mutual trust relationship with villagers. Because only in the process of continuous exchange and mutual guidance between the academic and the inhabitant, the core value of the rural heritage that meets the real interests of the villagers will be seen. By this means, the quality of Traditional Village protection plan can be prepared and improved with practical feasibility.

\section{Conclusion}

The Traditional Villages system, as a means of identifying and managing large quantities of rural heritage in China, constitutes the dual-track inventory system for rural landscape with the Historical and Cultural Villages list. Regarding the assessment criteria and the number of recognitions, the Traditional Village list indicates the progress of the ideology of rural heritage preservation. However, without synchronous reform and innovation in the governance solutions and dynamic mechanism, the requirement of balance the preservation and development of rural heritage will be extremely challenging. In the context of current political and economic environments in China, the preservation of Traditional Villages is viewed not only as a tool for economic improvement, but also as a carrier of cultural renaissance. Although the farming life that has been passed down in China for thousands of years has suffered from the great impact of modernisation, the internal developmental power contained in the tangible and intangible rural heritage has not been exhausted, and its inherent beauty is still attracting people to work hard. The strategies, methodologies and management system will be explored through the extensive and ongoing cooperation among villagers, experts and officials.

\section{Acknowledgments}

We would like to thank all participants who took part in the field study project of Rural Heritage Survey in 2018.
We would also like to express our gratitude to all the villagers and the provincial, county, township officials who offered us valuable information and experience about practicing Traditional Villages in China. The project was supported by the national Ministry of HURD. The suggestions and comments of Dr. Ding Shi, Dr. Xiaomei Zhao and anonymous reviewers were particularly helpful in revising this paper. Special thanks for the help and support of Dr. Shi Hou, Dr. Ziyu Qi and especially, Mr. Shaoyuan Liu, who contributed with insightful observations to the project.

\section{References}

ASKCI Consulting. 2018. "Research Report on China's Rural Tourism Market Prospect in 2018”. http:// wk.askci.com/details/1096/

Davis, Peter. 1999. Ecomuseums: A Sense of Place. London: Leicester University Press

Gao, Shunli, Songshan Huang, and Yucheng Huang. 2009. "Rural Tourism Development in China". International Journal of Tourism Research, no. 11: 439-450

Kuai, Yanli. 2016. "Research on Traditional Villages' Protection System in China." [Woguo chuantong cunluo baohu zhidu de fansi yu chuangxin.] Modern Urban Research, no. 1: 2-9.

Li, Qiang, Yulin Chen and Jingming Liu. 2012. “On the Development Mode of Chinese Urbanization." [Zhongguo Chengzhenhua Tuijin Moshi Yanjiu.] Social Sciences in China, no. 7: 82-100.

Nitzky, William. 2012. "Mediating Heritage Preservation and Rural Development: Ecomuseum Development in China." Urban Anthropology and Studies of Cultural Systems and World Economic Development 41 (2/3/4): 367-417.

Oakes, Tim. 2000. "China's Provincial Identities: Reviving Regionalism and Reinventing 'Chineseness"' Journal of Asian Studies 59 (3): 667-692.

Oakes, Tim. 2013. "Heritage as Improvement: Cultural Display and Contested Governance in Rural China”. Modern China 39 (4): 380-407.

Scazzosi, Lionella and Xi Wang, Jingyu Li. 2018. "Contexts and Concept of Principles Concerning Rural Landscape as Heritage ICOMOS (2017)" [Guoji guji yizhi lishihui guanyu xiangcun yichan de zhunze (2017) chansheng de yujing yu gainian jiedu.] Chinese Landscape Architecture 34 (11): 5-9.

Shao, Yong and Juanjuan Fu. 2012. "Research on Valuebased Integrated Evaluation Framework of Historical and Cultural Towns and Villages in China." [Yi jiazhi 
wei jichu de lishi wenhua cunzhen zonghe pingjia yanjiu.] City Planning Review 36 (2): 82-88.

State Council. 2013. "Several Opinions on Accelerating the Development of Modern Agriculture and Further Enhancing the Vitality of Rural Development." Accessed 21 June 2019. http://www.gov.cn/jrzg/201301/31/content_2324293.htm

State Council. 2014. "Several Opinions on Comprehensively Deepening Rural Reform and Accelerating Agricultural Modernization.” Accessed 21 June 2019. http:// www.gov.cn/zhengce/2014-01/19/content_2640103. htm

State Council. 2015. "Several Opinions on Increasing Reform and Innovation and Accelerating Agricultural Modernization Construction.” Accessed 21 June 2019. http://www.gov.cn/zhengce/2015-02/01/content_2813034.htm

State Council. 2016. "Several Opinions on Implementing the New Concept of Development, Accelerating Agricultural Modernization and Realizing the Goal of Comprehensive Well-off Society." Accessed 21 June 2019. http://www.gov.cn/zhengce/2016-01/27/content_5036698.htm

State Council. 2017. "Several Opinions on Deepening the Structural Reform of Agricultural Supply Side and Accelerating the Development of New Kinetic Energy for Agricultural and Rural Development." Accessed 21 June 2019. http://www.gov.cn/zhengce/2017-02/05/ content_5165626.htm

State Council. 2018. "Opinions of the Central Committee of the Communist Party of China on Implementing the Rural Revitalization Strategy." Accessed 21 June 2019. http://www.gov.cn/zhengce/2018-02/04/content_5263807.htm

State Council. 2019. "Several Opinions on Adhering to the Priority Development of Agriculture and Countryside and Doing a Good Job in 'Three Rural Issues"” Accessed 21 June 2019. http://www.gov.cn/ zhengce/2019-02/19/content_5366917.htm

Svensson, Marina. 2016. "Evolving and Contested Cultural Heritage in China: the Rural Heritagescape.” In Reconsidering Cultural Heritage in East Asia, edited by Akira Matsuda and Luisa Elena Mengoni, 31-46. London: Ubiquity Press.

Taylor. Ken. Translated by Han Feng and Tian Feng. 2007. "Cultural Landscapes and Asian Values: Negotiating a Transition from an International Experience to an Asian Regional Framework." Chinese Landscape Architecture, no. 11: 4-9.
Xu, Yuanwang, and Lu Lu. 2011. "From Governmentled to Participatory Development: The Path Choice of Rural Community Construction in China." [Cong zhengfu zhudao dao canyushi fazhan: zhongguo nongcun jianshe de lujing xuanze.] Academic Journal of Zhongzhou 181 (1): 120-124.

Zhang, Chengyu. 2011. “Two Activities about Village Cultural Landscape's Conservation and Sustainable Development: Analyzing Eco-museum and Rural Tourism" [Cunluo wenhua jingguan baohu yu ke chixu fazhan de liang zhong shijian.] Tongji University Journal Social Science Section 22 (3): 35-44.

Zhang, Song. 2012. "On the Basic Characters and Chanllenge of the Conservation Mechanism in Historic and Cultural Cities.” [Lishi wenhua mingcheng de zhidu tezheng yu xianshi tiaozhan.] Urban Studies 19 (9): 5-11.

Zhou, Jian, and Xiaohua Zhong. 2015. "Rural Heritage Preservation from the Perspective of Development: Case Study of Dong Ethnic Villages." [Fazhan shijiao xia de xiangcun yichan baohu lujing tantao: dongzu cunzhai tianye gongzuo anli.] Urban Planning Forum 221 (1): 54-60.

Zhou, Mengyuan, and Xiaofan Du. 2019. “The Progressive Concept and Practice on Assessment of Cultural Heritage Value." Palace Museum Journal 201 (1): 15-25. 